\title{
First record of Cebidicola semiarmatus (Phthiraptera: Trichodectidae) on the red howler monkey, Alouatta guariba clamintans (Primate: Atelidae) in Brazil
}

\author{
Primer registro de Cebidicola semiarmatus (Phthiraptera: Trichodectidae) en el mono aullador rojo, \\ Alouatta guariba clamintans (Primates: Atelidae) en Brasil
}

\section{RAFAEL MOREIRA DO NASCIMENTO ${ }^{1}$, RALPH MATURANO ${ }^{2}$, MARIANA DE OLIVEIRA ${ }^{3}$ and ERIK DAEMON ${ }^{4}$}

\begin{abstract}
Lice are highly specialized parasites that spend their entire life cycle on their host. Thus, a particular species of chewing lice is often restricted either to a single host species or to a phylogenetically related species. About 560 species of these insects parasitize mammals exclusively. Cebidicola semiarmatus is one of these species, known to parasitize several primate species of the genus Aloautta. This paper presents the first record of $C$. semiarmatus parasitizing $A$. guariba clamintans.
\end{abstract}

Key words: Ectoparasites, wildlife, insects, mammals.

\begin{abstract}
Resumen: Los piojos son parásitos especializados que desarrollan todo su ciclo de vida en el hospedador. Por esta razón, muchas veces una determinada especie de piojo masticador es específica de una especie de hospedador o de otras filogenéticamente cercanas próximas. Alrededor de 560 especies de piojos parasitan exclusivamente mamíferos. Cebidicola semiarmatus, es una de ellas, caracterizada por parasitar primates del género Aloautta. Este trabajo constituye el primer registro de C. semiarmatus parasitando A. guariba clamintans.
\end{abstract}

Palabras clave: Ectoparásitos, fauna silvestre, insectos, mamíferos.

\section{Introduction}

The fauna of chewing lice parasitizing primates of the genus Alouatta Lacépède, 1799 in Brazil has not been properly studied since Werneck's late works (1950), in which some species of lice, as well as associations between parasites and hosts, were described. Thus, this report makes a contribution to knowledge regarding parasites likely to occur in Alouatta guariba clamintans Cabrera, 1940.

Lice (Phthiraptera) are highly specialized parasitic insects, with generally high specificity, unlike most other ectoparasite insects (Marshall 1981). They include bloodsucking species (Suborder Anoplura, restricted to mammals) and chewing species (Suborders Amblycera, Ischnocera and Rhyncophthirina, parasitizing birds and/ or mammals). Because they spend their entire life cycle on the host, a particular species of chewing louse is often restricted to a certain host species or to a phylogenetically related species (Barker 1994; Johnson and Clayton 2003). There are about 5,000 known species of lice, and among these about 560 are specific parasites of mammals (Price et al. 2003). Cebidicola semiarmatus (Neuman, 1913) is one of these species, having been found parasitizing Alouatta caraya (Humboldt, 1812), A. belzebul (Linnaeus, 1766), and A. seniculus ursina (Linnaeus, 1766) (Werneck 1950), popularly known as the black howler monkey, and red howler monkey and brown howler monkey, respectively (Bicca-Marques et al. 2006).
Alouatta guariba clamitans, popularly known as the red-handed howler monkey, is widely found throughout the Atlantic Forest (Bicca-Marques et al. 2006). The presence of parasites on Alouatta is common, as they are an ecological mediator, able to regulate populations due to the clinical and/ or sub-clinical manifestation of diseases, as well as mortality as a consequence in some of these animals (Freeland 1976). Endoparasites of howler monkeys are well studied (Stuart et al. 1998), and the contrary happens regarding chewing lice. Knowledge about these interactions is of paramount importance for understanding many ecological aspects of these animals. This report presents the first record of $C$. semiarmatus parasitism in A. g. clamitans.

\section{Materials and methods}

Lice specimens were obtained in July 2015 from a howler monkey that was a victim of tramping, in the city of Matias

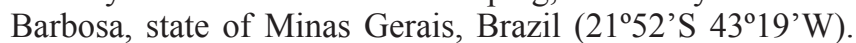
The howler monkey examined was a female, belonging to the A. g. clamitans subspecies, according to Gregorin (2006). It was brought to the Wild Animal Screening Center (CETAS, Portuguese acronym) located at the headquarters of the Brazilian Environmental Institute (IBAMA, Portuguese acronym) in the city of Juiz de Fora, Minas Gerais. The primate was visually examined for the presence of ectoparasites. Since the presence of lice was noticed, they were collected

\footnotetext{
${ }^{1}$ Student. Programa de Pós-Graduação em Ciências Biológicas, Comportamento e Biologia Animal, Universidade Federal de Juiz de Fora, Juiz de Fora, Minas Gerais, Brasil, rafael_mnascimento@yahoo.com.br. ${ }^{2}$ Ph. D. Departamento de Zoologia, Universidade Federal de Juiz de Fora, Juiz de Fora, Minas Gerais, Brasil. ${ }^{3}$ M. Sc. Programa de Pós-Graduação em Ciências Veterinárias, Universidade Federal Rural do Rio de Janeiro, Rio de Janeiro, RJ, Brasil. ${ }^{4}$ Ph. D. Deseased. Corresponding author: Rafael Moreira do Nascimento. Student. Programa de Pós-Graduação em Ciências Biológicas, Comportamento e Biologia Animal, Universidade Federal de Juiz de Fora, Juiz de Fora, Minas Gerais, Brasil, rafael_mnascimento@yahoo.com.br.
} 
with tweezers, packed in bottles containing $70^{\circ}$ ethanol and then forwarded to the Laboratory of Parasite Arthropods of Federal University of Juiz de Fora. These insects were mounted on permanent slides, according to adaptations to the technique proposed by Palma (1978). Lice were then identified through appropriate keys (Werneck 1950; Price et al. 2003), and deposited in the laboratory's collection.

\section{Results and discussion}

Thirty lice $C$. semiarmatus (Fig. 1) were found, among them eleven females (Fig. 1A), five males (Fig. 1B) and fourteen nymphs. Nits were found on the host's head and forelegs. Lice were distributed throughout the belly, back and head. The proposition of new associations between lice and host is a controversial subject in the Phthiraptera order, given the particularities they present (Valim et al. 2005). However, this is the first record of C. semiarmatus parasitism in $A . g$. clamitans.

According to Kethley and Johnston (1975), parasites can be transferred between hosts. Thus, a louse can parasitize a second host presenting similar conditions as the first one. Therefore, this association can be explained by the fact that $A$. g. clamitans and A. caraya are able to generate hybrid individuals (Jesus et al. 2010), thereby being considered closely related species from the phylogenetic point of view. In addition, $A$. g. clamitans, $A$. caraya and $A$. belzebul have similar characteristics, such as body size and hair thickness; however, fur morphology is different, as is the distribution of scales on the cuticle and the cell shape in the marrow (Ingberman and MonteiroFilho 2006). These are some of the mechanisms which may define the specificity of mammal lice (Reed et al. 2000). Therefore, it is possible that A. g. clamitans has favorable characteristics for parasitism by $C$. semiarmatus and the internal and external morphology of the fur does not interfere directly in the parasite specificity mechanism, with thickness having the only influence.

According to Taylor and Purvis (2003), Trichodectidae family lice and mammals do not show a co-speciation process. However, according to those authors, there may still be unknown factors exerting influence on the co-speciation process. A direct effort is needed to research Phthiraptera fauna in primates, since the comprehension of this group might assist in health management measures, as well as to elucidate aspects concerning to the phylogenetic of these animals.

\section{Acknowledgements}

We thank Coordenação de Aperfeiçoamento de Pessoal de Nível Superior (CAPES) and Conselho Nacional de Desenvolvimento Científico e Tecnológico (CNPq) for funding.

\section{Literature cited}

BARKER, S. C. 1994. Phylogeny and classification, origins, and evolution of host associations of lice. International Journal for Parasitology 24: 1285-1291.
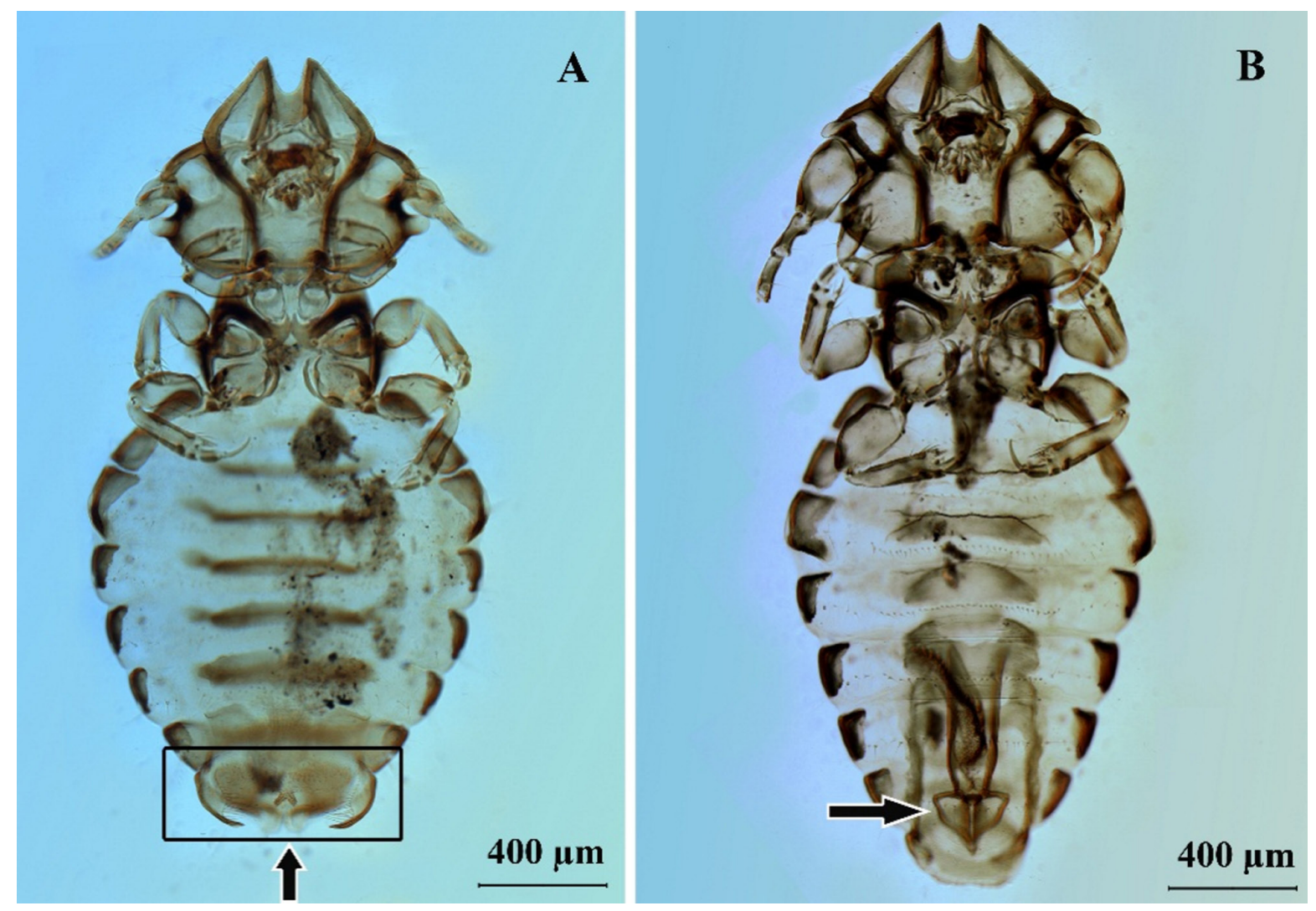

Figure 1. Specimens of Cebidicola semiarmatus. A. Female, highlighting the last tergite of subgenital plate, with numerous small setae. B. Male, highlighting the posterior portion of the reproductive tract. 
BICCA-MARQUES, J. C.; SILVA, V. M.; GOMES, D. F. 2006. Ordem Primates, pp. 101-147. In: Reis, N. R.; Peracchi, A. L.; Pedro, W. A.; Lima, I. P. (Eds.). Mamíferos do Brasil. Londrina, Technical Books. 437 p.

FREELAND, W. J. 1976. Pathogens and the evolution of primate sociality. Biotropica 8: 12-24.

GREGORIN, R. 2006. Taxonomia e variação geográfica das espécies do gênero Alouatta Lacépède (Primates, Atelidae) No Brasil. Revista Brasileira de Zoologia 23: 64-144.

INGBERMAN, B.; MONTEIRO-FILHO, E. L. 2006. Identificação microscópica dos pêlos das espécies brasileiras de Alouatta Lacépède, 1799 (Primates, Atelidae, Alouattinae). Arquivos do Museu Nacional (Rio de Janeiro) 64: 61-71.

JESUS, A. S.; SCHUNEMANN, H. E.; MULLER, J.; DA SILVA, M. A.; BICCA-MARQUES, J. C. 2010. Hybridization between Alouatta caraya and Alouatta guariba clamitans in captivity. Primates 51: 227-230.

JOHNSON, K. P.; CLAYTON, D. H. 2003. The biology, ecology, and evolution of chewing lice. pp. 449-476. In: Price, R. D.; Hellental, R. A.; Palma, R. L.; Johnson, K. P.; Clayton, D. H. (Eds.). The chewing lice: world checklist and biological overview. Illinois Natural History, Survey Special Publication 24. $\mathrm{X}+501 \mathrm{p}$.

KETHLEY, J. B.; JOHNSTON, D. E. 1975. Resource tracking patterns in bird and mammal ectoparasites. Miscellaneous Publications of the Entomological Society of America 9: 231236.

MARSHALL, A. G. 1981. The ecology of ectoparasitic insects. Academic Press. 459 p.

PALMA, R. L. 1978. Slide-mounting of lice: a detailed description of the Canada balsam technique. The New Zealand Entomologist 6: 432-436.

PRICE, R. D.; HELLENTHAL, R. A.; PALMA, R. L. 2003. World checklist of chewing lice with host associations and keys to families and genera. pp. 1-448. In: Price, R. D.; Hellental, R. A.; Palma, R. L.; Johnson, K. P.; Clayton, D. H. (Eds.). The chewing lice: world checklist and biological overview. Illinois Natural History, Survey Special Publication 24. X+501 p.

REED, D. L.; HAFNER, M. S.; ALLEN, S. K. 2000. Mammalian hair diameter as a possible mechanism for host specialization in chewing lice. Journal of Mammalogy 81: 999-1007.

STUART, M.; PENDERGAST, V.; RUMFELT, S.; PIERBERG, S.; GREENSPAN, L.; GLANDER, K.; CLARKE, M. 1998. Parasites of wild howlers (Alouatta spp.). International Journal of Primatology 19: 493-512.

TAYLOR, J.; PURVIS, A. 2003. Have mammals and their chewing lice diversified in parallel? pp. 240-261. In: Page, R. D. M. (Ed.). Tangled trees: phylogeny, cospeciation and coevolution. Chicago, University of Chicago. 378 p.

VALIM, M. P.; TEIXEIRA, R. H. F.; AMORIM, M.; SERRAFREIRE, N. M. 2005. Malófagos (Phthiraptera) recolhidos de aves silvestres no zoológico de São Paulo, SP, Brasil. Revista Brasileira de Entomologia 49: 584-587.

WERNECK, F. L. 1950. Os Malófagos de mamíferos: Ischnocera (continuação de Trichodectidae) e Rhyncophthirina. Parte 2. Edição do Instituto Oswaldo Cruz. 207 p.

Received: 24-Sep-2016 • Accepted: 22-Sep-2017

Suggested citation:

NASCIMENTO, R. M.; MATURANO, R.; OLIVEIRA, M. de; DAEMON, E. 2018. First record of Cebidicola semiarmatus (Phthiraptera: Trichodectidae) on the red howler monkey, Alouatta guariba clamintans (Primate: Atelidae) in Brazil. Revista Colombiana de Entomología 44 (1): 129-131. Enero Junio 2018. 